\title{
O Estado e a habitação numa encruzilhada?
}

\author{
Nuno Serra (Centro de Estudos Sociais, Universidade de Coimbra), Portugal.
}

Há cerca de doze anos, quando a crise financeira não tinha ainda desabado sobre a economia e a sociedade portuguesa - e, portanto, antes ainda da sua transmutação em «crise das dívidas soberanas» - muito dificilmente se poderia antever o tipo de problemas e de questões que hoje se colocam no domínio da habitação e das políticas de alojamento.

De facto, em resultado de uma política habitacional centrada na generalização do crédito para aquisição de casa própria, desde meados dos anos oitenta, e com a execução de um programa público criado para acabar de vez com as barracas nas áreas metropolitanas de Lisboa e Porto, já no início dos anos noventa, julgarse-ia que a endémica situação de «crise habitacional» estaria finalmente superada em Portugal. Ou seja, o que as tímidas políticas de promoção direta não conseguiram durante décadas fora aparentemente alcançado através do mercado, numa combinação entre o acesso fácil a crédito abundante e com baixas taxas de juro e medidas de natureza fiscal orientadas para a bonificação pública dos empréstimos. $\mathrm{O}$ acesso à propriedade, através da expansão da casa própria como forma preferencial de ocupação, fortalecia essa ideia, de um problema estrutural finalmente ultrapassado.

Hoje, porém, existem fundadas razões para que se possa falar no surgimento de uma nova «crise de habitação», que resulta da convergência de diversos fatores, incluindo dinâmicas inesperadas ou mais difíceis de antever, como sucede com a explosão da procura turística, sobretudo nas grandes cidades, e a consequente proliferação do alojamento local. Isto é, dinâmicas que se somaram ao efeito de medidas com impacto no mercado habitacional, de que são exemplo os Vistos Gold ou as alterações, no sentido da maior liberalização, ao mercado de arrendamento. Isto para já não falar, evidentemente, do papel que a recuperação da economia, do mercado de trabalho e dos rendimentos tiveram, depois dos anos de austeridade e de «ajustamento», na revitalização da procura e na reativação da construção e reabilitação do edificado. Ou seja, fatores que, no seu conjunto, permitem compreender por que razão se assiste a um novo ciclo de subida dos preços da habitação, tanto na esfera da compra como do arrendamento, a par de novas dinâmicas de escassez de oferta, de exclusão e de insolvência, ou mesmo de expulsão de agregados familiares com menores rendimentos para a periferia das grandes cidades ou para concelhos limítrofes das áreas metropolitanas.

Os tempos que atravessamos são, contudo, bastante mais complexos. Ao mesmo tempo que surgem estes sinais, hoje já evidências, de uma nova crise habitacional, emergem igualmente indícios da possibilidade de estar em curso uma mudança de paradigma das políticas de habitação, suscetível de estabelecer uma rutura com abordagens avulsas e descoordenadas, a persistência de modelos serôdios de promoção habitacional ou intervenções públicas há muito marcadas pelo minimalismo em termos de política social. É pelo menos isso que parece anunciar a Nova Geração de Políticas de Habitação, recentemente aprovada pelo Governo e que não pode seguramente deixar de ser interpretada, também, enquanto tentativa de resposta, mais robusta, integrada e transversal, à atual crise de alojamento. Ou, ainda, mas neste caso há muito sentida como em falta na arquitetura jurídica e institucional do Estado Social português, a elaboração e discussão de uma Lei de Bases da Habitação, cujo atraso em alcançar a luz do dia é bem revelador do lugar secundário que o setor tem ocupado no quadro das políticas sociais em Portugal e da consciência, acumulada, de défice de Estado, neste importante domínio da intervenção social pública, em termos de universalidade e acesso.

É perante este quadro mais geral que o conjunto de textos e reflexões reunidos na presente edição da revista «Cidades: Comunidades e Territórios» reflete, de forma certeira, substantiva e oportuna, o ponto de encruzilhada em que a questão da habitação hoje se encontra e que é determinado, em ampla medida, pela 
capacidade que a Nova Geração de Políticas de Habitação venha a demonstrar para dar uma resposta robusta e consequente aos problemas e desafios que se lhe colocam. E desse ponto de vista o contributo destas reflexões situa-se essencialmente em três planos.

Procede-se, por um lado, e com uma perspetiva de futuro, à avaliação crítica das políticas que têm caraterizado a atuação do Estado no setor, procurando-se evidenciar as razões do seu relativo insucesso e as limitações dos modelos preferencialmente seguidos até aqui. Para além da recorrente propensão para soluções minimalistas no âmbito da promoção direta de alojamentos, que circunscreve as respostas públicas às situações mais prementes de carência habitacional, é assinalada a preferência, também ela recorrente, de atuar através do mercado, sendo nestes termos questionada a efetiva capacidade de desmercadorização da habitação e de regulação da iniciativa privada.

Em segundo lugar, desenvolve-se nesta edição uma análise crítica, construtiva e exigente das medidas de política habitacional que consubstanciam a Nova Geração de Políticas de Habitação. Com efeito, sem deixar de reconhecer o mérito subjacente à estruturação de uma abordagem integrada, transversal e multidimensional (há quanto tempo não dispúnhamos de uma «política de habitação» com estas caraterísticas?), identificam-se os seus riscos, incertezas e fragilidades. É aliás neste ponto, sobretudo neste ponto, que a relação entre o atual estado de crise do alojamento e a intencionalidade política melhor espelham a ideia de encruzilhada.

Por último, deve assinalar-se o facto de várias reflexões integrantes deste número constituírem igualmente um importante contributo para que, perante a incerteza quanto à eficácia das políticas propostas, a «saída» da encruzilhada se faça, o mais possível - e atendendo nomeadamente às limitações orçamentais com que o país se defronta - pelo caminho melhor sucedido. É neste sentido, por exemplo, que se salienta a relevância dos processos de envolvimento e participação das comunidades, a adequada articulação de escala ao nível da governação das políticas de habitação ou a importância de melhorar a recolha e sistematização de informação, a par de uma maior mobilização do conhecimento e da investigação.

Estamos pois perante um número da «Cidades: Comunidades e Territórios» que soube captar bem o «espírito do tempo» e que, mobilizando as aprendizagens do passado e assinalando as exigências do futuro, identifica muitos dos aspetos essenciais para uma efetiva mudança da política de habitação em Portugal.

Copyright $(C) 2019$ (Serra, N.)

Licensed under the Creative Commons Attribution Non-commercial No Derivatives.

Available at http://revistas.rcaap.pt/cct/ DOI: 10.15847/citiescommunitiesterritories.jun2019.038.tes02 